\title{
The Effect of Leaflet on Hypertension Knowledge in Hypertensive Patients in Community Health Center in Surabaya City
}

\author{
lin Ernawati*, Selly Septi Fandinata, Silfiana Nisa Permatasari \\ Akademi Farmasi Surabaya, Surabaya Indonesia
}

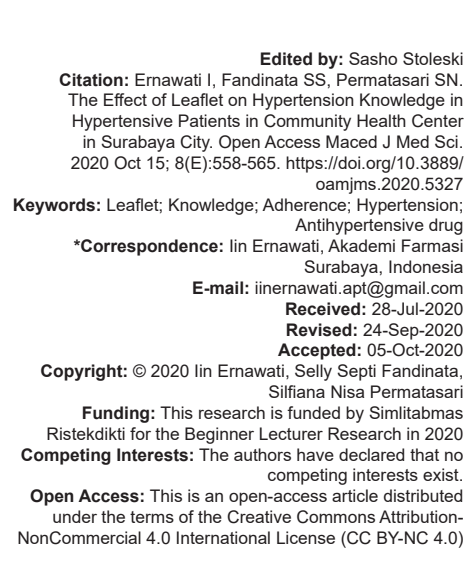

\section{Introduction}

Hypertension is a chronic disease that is currently increasing in prevalence and requires longterm care [1]. Hypertension is defined as a systolic blood pressure of $\geq 140 \mathrm{mmHg}$ and diastolic blood pressure of $\geq 90 \mathrm{mmHg}$ [2], [3]. The prevalence of hypertension is increasing globally and is the most increasing in lowmiddle income countries [3]. The prevalence in general worldwide is estimated at $31.1 \%$ and will affect 1.39 billion people [4]. The prevalence of hypertension in Indonesia based on a population survey until 2018, it is known that the age of $\geq 18$ years diagnosed by doctors is $34.1 \%$ [5]. Hypertension is a risk factor that causes 1.5 million deaths per year in Southeast Asia [6]. The death of $45 \%$ of cardiovascular disease is caused by the presence of non-communicable diseases, with the main risk factor being uncontrolled hypertension [3]. Based on the WHO data, it was found that 56.4 million deaths occurred in 2015 , with an average of $70 \%$ of deaths contributing to non-communicable diseases, including hypertension [7].

Blood pressure control is one of the efforts to reduce the prevalence of hypertension. Blood pressure control can be carried out using antihypertensive drugs and lifestyle modification to avoid complications of cardiovascular diseases such as stroke, heart disease, diabetes mellitus, and kidney [8], [9], [10]. Controlled blood pressure is predominantly affected by the administration of drugs according to the disease, adequate dosage, and adherence to therapeutic regimens [3]. Adherence with drug consumption and the accuracy of drug administration are two things that must be done on an ongoing basis to control blood pressure, apart from lifestyle factors.

Based on research from Hill et al. [11], it is known that adherence to drug consumption during the first year using antihypertensive drugs is only around $50 \%$. The number of adult patients with hypertension in low-middleincome countries is known to have a high proportion of uncontrolled blood pressure [4]. This happens one of them due to the impact of suboptimal adherence that causes uncontrolled blood pressure [3]. Increased knowledge about hypertension is one way to increase understanding of things related to hypertension, both in terms of lifestyle, diet, adherence to medication, and complications. The level of knowledge of hypertensive patients is one of the factors that influence adherence to the treatment regimen and the patient's lifestyle. 
Research by Saleem et al. [12] stated that the lack of knowledge and trust in the treatment of hypertension is a factor that affects the quality of life of patients. Knowledge and awareness are strong predictors of prevention and treatment adherence of hypertensive patients [13], [14], [15]. The knowledge is given to the general public and hypertensive patients are carried out in several ways, including providing educational interventions and behavioral changes. Interventions that can improve adherence to hypertensive patients can be carried out including by doctors (providing information about hypertension and risk of complications), direct intervention in patients (self-monitoring of blood pressure, giving instructions or motivational strategies, and simplifying drug regimens), or interventions on the health system [3]. Other interventions to improve adherence are behavioral interventions such as the provision of instruments to improve patients' memories of taking the medication regularly [16], [17].

Based on research from Ekpenyong et al. [18], education or health education interventions can increase knowledge. Other studies state that community-based educational interventions with adult and elderly patient subjects can increase knowledge, prevention, and selfcare for hypertensive patients [19]. Leaflet interventions are educational interventions or information on matters related to hypertension given to hypertensive patients through leaflets. The leaflet used contains the definition of blood pressure in hypertension, diet, lifestyle, and the importance of adherence to medication consumption according to the regimen recommended by doctors to control blood pressure. The purpose of this study was to determine the effect of leaflet administration on the level of knowledge of hypertensive patients. Measurement of the level of knowledge in this study uses the hypertension knowledge-level scale (HK-LS) questionnaire [20].

\section{Participants and Methods}

\section{Participant}

Hypertensive patients who are on the diagnosis of hypertension and receiving antihypertensive drug therapy were enrolled for the current study (inclusion criteria).

\section{Instrument}

This study uses the HK-LS questionnaire [20], which the researcher has translated into the Indonesian version and tested for validation and reliability, leaflets and medical records for informed consent and forms for consent patients.

\section{Methods}

This research is a quasi-experimental research with an intervention group (given leaflet) and a control group (not given leaflet). The research subjects were given informed consent containing an explanation of the research and the research subject's consent form. For informed consent and forms for consent, HK-LS questionnaire [20], which the researcher has translated into Indonesian version, was given online or telephone. If prospective research subjects are willing to be contacted by telephone or text message or WhatsApp, then the questionnaire can be sent through the Google form link. For research subjects who have difficulty using mobile phones or short message applications can be represented by family members or people who monitor taking research subjects' drugs. This research was conducted at 5 Community Health Centers (Jeruk, Ketabang, Gayungan, Tambakrejo, Benowo) in Surabaya City. This research was conducted in May-June 2020. This research has been submitted to the ethics committee of the Faculty of Public Health, Airlangga University, with the ethical approval number: 96/EA/KEPK/2020.

\section{Inclusion criteria}

The following criteria were included in the study:

- Patient (20-70) years of diagnosis of hypertension and receiving antihypertensive drug therapy

- $\quad$ Patients with complete data (medical records and prescription drugs)

- $\quad$ Patients who visit the community health center at least take antihypertensive drugs for 1 month

Patients who are willing to be contacted through a WhatsApp or telephone or text message.

\section{Exclusion criteria}

The following criteria were excluded from the study:

- $\quad$ Patients with hypertension in children

- $\quad$ Patients in pregnant and nursing women who suffer from hypertension

- $\quad$ Patients with incomplete medical record data

- Patients with mental retardation.

\section{Drop out criteria}

Patients who have entered the inclusion criteria but dropped out

Patients who have entered inclusion criteria have changed drug treatment regimens based on doctor's orders. 


\section{Knowledge of hypertension}

Measurement of the level of knowledge in this study uses the HK-LS questionnaire [20], which the researcher has translated into the Indonesian version and tested for validation and reliability. Based on the validity test, it was known that all HK-LS statement items were valid. For the reliability test, it was known that the Cronbach's alpha coefficient of hypertension was 0.758 . The level of knowledge using the HK-LS questionnaire consisting of 22 statement items has three answer choices, including "true," "false," and "don't know." Each correct answer from the HK-LS questionnaire scores 1. The maximum score from the HK-LS questionnaire is 22. [21]. The level of hypertension knowledge using the HK-LS questionnaire was divided into two levels, namely, low knowledge (score $\leq 17$ ) and high knowledge (score 18-22) [22].

\section{Statistical analysis}

The analysis of the results in this study is based on Key Performance Indicator (KPIs) which are used to see how the effect of leaflet intervention on outcome indicators of hypertensive patients. Performance indicators of hypertension management in this study are the knowledge level of hypertension, mean systolic blood pressure, mean diastolic blood pressure, the prevalence of hypertension, and prevalence of controlled hypertension. The normality of data distributions was verified using the Shapiro-Wilk and Lilliefors test. Qualitative and ordinal variables were grouped in contingency tables, with numbers (n) and percentage (\%) calculated. The independence of qualitative characteristics in control, pre- and postintervention was verified using Pearson's chi-squared test. Pearson's chi-squared test checks for differences in the proportion of a variable among the groups. Comparative statistical analysis between low and high knowledge levels in the studied group using the MannWhitney test. Statistical testing of the influence of leaflets on knowledge (control and intervention groups) was carried out non-parametric (Mann-Whitney) data analysis, for the pre-test and post-test was verified using Wilcoxon analysis. Statistical analysis in this study was conducted using SPSS version 20 Software.

\section{Results}

\section{Patients characteristics}

Research on the effect of leaflet administration on the level of hypertension knowledge measured using the HK-LS questionnaire using 387 samples (193 control subjects and 194 treatment subjects received leaflets). Based on sociodemographic data, in the control and intervention groups, it is known that the majority of respondents are female with an age range of 40-60 years. The type of therapy that uses antihypertensive drugs is monotherapy. Most educational backgrounds are a senior high school, with the majority level of knowledge being a low level of knowledge as measured using the HK-LS questionnaire (Table 1). In the control group, the mean systolic blood pressure was $143.53 \mathrm{mmHg}$ and diastolic blood pressure $83.13 \mathrm{mmHg}$. However, in the pre-intervention group, the average systolic blood pressure was $143.48 \mathrm{mmHg}$, and diastolic blood pressure $83.7 \mathrm{mmHg}$. The post-intervention group giving leaflets had a change in the average systolic blood pressure to $136.5 \mathrm{mmHg}$ and diastolic blood pressure to $79 \mathrm{mmHg}$ (Table 1).

Table 1: Baseline characteristic

\begin{tabular}{|c|c|c|c|c|c|c|}
\hline \multirow[t]{2}{*}{ Sociodemographic characteristic } & \multicolumn{2}{|c|}{$\begin{array}{l}\text { Baseline } \\
\text { Control } \\
\text { ( } \mathrm{n} \text { total }=193\end{array}$} & \multicolumn{2}{|c|}{$\begin{array}{l}\text { Before } \\
\text { Intervention } \\
(\mathrm{n} \text { total }=194)\end{array}$} & \multicolumn{2}{|c|}{$\begin{array}{l}\text { After } \\
\text { Intervention } \\
(\mathrm{n} \text { total = 194) }\end{array}$} \\
\hline & $\mathrm{n}$ & $\%$ & $\mathrm{n}$ & $\%$ & $\mathrm{n}$ & $\%$ \\
\hline \multicolumn{7}{|l|}{ Gender } \\
\hline Male & 59 & 30.57 & 134 & 69.07 & 134 & 69.07 \\
\hline Female & 134 & 69.43 & 60 & 30.93 & 60 & 30.93 \\
\hline \multicolumn{7}{|l|}{ Age } \\
\hline $20-40$ years & 8 & 4.14 & 9 & 4.64 & 9 & 4.64 \\
\hline $41-60$ years & 104 & 53.89 & 105 & 54.12 & 105 & 54.12 \\
\hline$>60$ years & 81 & 41.97 & 80 & 41.24 & 80 & 41.24 \\
\hline \multicolumn{7}{|l|}{ Type of therapy } \\
\hline Monotherapy & 179 & 92.75 & 170 & 87.63 & 170 & 87.63 \\
\hline Combination & 14 & 7.25 & 24 & 12.37 & 24 & 12.37 \\
\hline \multicolumn{7}{|l|}{ Background education } \\
\hline Elementary high school & 57 & 29.53 & 61 & 31.44 & 61 & 31.44 \\
\hline Junior high school & 26 & 13.47 & 29 & 14.95 & 29 & 14.95 \\
\hline Senior high school & 71 & 36.79 & 71 & 36.60 & 71 & 36.6 \\
\hline Diploma degree & 7 & 3.63 & 3 & 1.55 & 3 & 1.55 \\
\hline Bachelor and master degree & 32 & 16.58 & 30 & 15.46 & 30 & 15.46 \\
\hline \multicolumn{7}{|c|}{ Level of knowledge (HK-LS questionnaire) } \\
\hline Low (score $\leq 17)$ & 130 & 67.36 & 168 & 86.6 & 72 & 37.11 \\
\hline High $($ score $>17$ ) & 63 & 32.64 & 26 & 13.4 & 122 & 62.89 \\
\hline \multicolumn{7}{|l|}{ Blood pressure } \\
\hline $\begin{array}{l}\text { Systolic and diastolic blood } \\
\text { pressure } \geq 140 / 90 \mathrm{mmHg}\end{array}$ & 152 & 78.76 & 165 & 85.05 & 133 & 68.56 \\
\hline $\begin{array}{l}\text { Systolic and diastolic blood } \\
\text { pressure }<140 / 90 \mathrm{mmHg}\end{array}$ & 41 & 21.24 & 22 & 11.34 & 61 & 31.44 \\
\hline $\begin{array}{l}\text { Mean systolic blood pressure } \\
(\mathrm{mmHg})\end{array}$ & \multicolumn{2}{|c|}{143.53} & \multicolumn{2}{|c|}{143.48} & \multicolumn{2}{|c|}{136.5} \\
\hline $\begin{array}{l}\text { Mean diastolic blood pressure } \\
(\mathrm{mmHg})\end{array}$ & \multicolumn{2}{|c|}{83.13} & \multicolumn{2}{|l|}{83.7} & \multicolumn{2}{|l|}{79} \\
\hline
\end{tabular}

Characteristic of knowledge level based on HK-LS questionnaire

The percentage of each sociodemographic factor (baseline characteristic) to the level of hypertension knowledge is shown in Table 2. The level of knowledge of hypertension measured using the HK-LS questionnaire can be divided into two levels, namely, low level (score $\leq 17$ ) and high level (score $>$ 17) [21]. In Table 2, it is known that the majority of the three groups studied (control, pre-intervention, and post-intervention) had a low percentage of knowledge of hypertension. Based on the Pearson Chi-square test, individual characteristics on the level of knowledge of hypertension, such as gender, age, type of therapy, and level of education, do not affect the level of knowledge of hypertension (low and high). However, systolic blood pressure that exceeds normal in the intervention group (pre and post) influences the 
Table 2: Knowledge level (HK-LS questionnaire)

\begin{tabular}{|c|c|c|c|c|c|c|c|c|c|}
\hline \multirow[t]{3}{*}{ Nominal (qualitative) variable of characteristic } & \multicolumn{3}{|l|}{ Baseline } & \multicolumn{3}{|l|}{ Before } & \multicolumn{3}{|l|}{ After } \\
\hline & \multicolumn{2}{|c|}{ Control $(\mathrm{n}$ total $=193)$} & \multirow[t]{2}{*}{$p$-value } & \multicolumn{2}{|c|}{$\begin{array}{l}\text { Intervention (pre leaflet } \\
\text { intervention) }(\mathrm{n} \text { total }=194)\end{array}$} & \multirow[t]{2}{*}{$\mathrm{p}$-value } & \multicolumn{2}{|c|}{$\begin{array}{l}\text { Intervention (post leaflet } \\
\text { intervention) ( } \mathrm{n} \text { total }=194)\end{array}$} & \multirow[t]{2}{*}{$p$-value } \\
\hline & $\begin{array}{l}\text { Low-level } \\
\text { knowledge } \\
\text { (HK-LS score } \\
\leq 17)(\%)\end{array}$ & $\begin{array}{l}\text { High-level } \\
\text { knowledge } \\
\text { (HK-LS score } \\
>17)(\%)\end{array}$ & & $\begin{array}{l}\text { Low- level } \\
\text { knowledge } \\
\text { (HK-LS score } \\
\leq 17)(\%)\end{array}$ & $\begin{array}{l}\text { High-level } \\
\text { knowledge } \\
\text { (HK-LS score } \\
>17)(\%)\end{array}$ & & $\begin{array}{l}\text { Low-level } \\
\text { knowledge } \\
\text { (HK-LS score } \\
\leq 17)(\%)\end{array}$ & $\begin{array}{l}\text { High-level } \\
\text { knowledge } \\
\text { (HK-LS score> } \\
17)(\%)\end{array}$ & \\
\hline Gender & & & 0.253 & & & 0.852 & & & 0.034 \\
\hline Male & $32(16.58)$ & $27(13.99)$ & & $126(64.95)$ & $7(3.61)$ & & $29(14.95)$ & $32(16.49)$ & \\
\hline Female & $98(50.77)$ & $36(18.65)$ & & $43(22.16)$ & $18(9.3)$ & & $45(23.2)$ & $88(45.36)$ & \\
\hline Age & & & 0.921 & & & 0.325 & & & 0.378 \\
\hline $20-40$ years & $5(2.59)$ & $3(1.55)$ & & $46(23.71)$ & $7(3.6)$ & & $3(1.55)$ & $6(3.09)$ & \\
\hline $41-60$ years & $77(39.9)$ & $27(13.99)$ & & $43(22,16)$ & $18(9.28)$ & & $42(21.65)$ & $68(35.05)$ & \\
\hline$>60$ years & $60(31.09)$ & 27 (13.99) & & $73(37.63)$ & $7(3.6)$ & & $27(13.92)$ & $48(24.74)$ & \\
\hline Type of therapy & & & 0.554 & & & 0.769 & & & 0.410 \\
\hline Monotherapy & $130(67.36)$ & $49(25.39)$ & & $146(75.26)$ & $24(12.37)$ & & $58(29.9)$ & $113(58.25)$ & \\
\hline Combination & $8(4.15)$ & $6(3.1)$ & & $22(11.34)$ & $2(1.03)$ & & $12(6.18)$ & $11(5.67)$ & \\
\hline Education & & & 0.076 & & & 0.389 & & & 0.827 \\
\hline Elementary high school & $44(22.8)$ & $13(6.7)$ & & $59(30.41)$ & $2(1.03)$ & & $17(8.80)$ & $44(22.68)$ & \\
\hline Junior high school & $18(9.33)$ & $8(4.15)$ & & $24(12.37)$ & $5(2.58)$ & & $13(6.7)$ & $16(8.25)$ & \\
\hline Senior high school & $51(26.42)$ & $20(10.36)$ & & $61(31.44)$ & $10(5.15)$ & & $27(13.90)$ & $44(22.68)$ & \\
\hline Diploma degree & $6(3.1)$ & $1(0.52)$ & & $3(1.55)$ & $0(0)$ & & $0(0)$ & $3(1.55)$ & \\
\hline Bachelor and master degree & $20(10.36)$ & $12(6.21)$ & & $23(11.86)$ & $7(3.6)$ & & $14(7.2)$ & $16(8.24)$ & \\
\hline Mean knowledge (HK-LS score) & 13.56 & 19.69 & & 12.48 & 18.62 & & 14.53 & 19.8 & \\
\hline \multicolumn{10}{|l|}{ Blood pressure } \\
\hline Systolic blood pressure $\geq 140 \mathrm{mmHg}$ & $104(53.89)$ & $48(24.87)$ & 0.524 & $143(73.71)$ & $22(11.34)$ & 0.031 & $56(28.87)$ & 77 (39.69) & 0.01 \\
\hline Systolic blood pressure $<140 \mathrm{mmHg}$ & $35(18.13)$ & $6(3.1)$ & & $28(14.43)$ & $1(0.51)$ & & $18(9.27)$ & $43(22.16)$ & \\
\hline Diastolic blood pressure $\geq 90 \mathrm{mmHg}$ & $75(38.86)$ & $23(11.91)$ & 0.741 & $119(61.34)$ & $16(8.25)$ & 0.884 & $30(15.46)$ & $66(34.02)$ & 0.232 \\
\hline Diastolic blood pressure $<90 \mathrm{mmHg}$ & $64(33.16)$ & $31(16.06)$ & & $51(26.29)$ & $8(4.12)$ & & $42(21.65)$ & $56(28.86)$ & \\
\hline $\begin{array}{l}\text { Comparative analytical statistical between low } \\
\text { and high knowledge }\end{array}$ & & & $<0.001$ & & & $<0.001$ & & & $<0.001$ \\
\hline Comparative analytical statistical low-level & & & & & & 0.021 & & & \\
\hline \multicolumn{10}{|l|}{ knowledge in the control and pre-intervention } \\
\hline Comparative analytical statistical high-level & & & & & & 0.001 & & & \\
\hline \multicolumn{10}{|l|}{$\begin{array}{l}\text { knowledge in the control and pre-intervention } \\
\text { group }\end{array}$} \\
\hline Comparative analytical statistical low-level & & & & & & & & & 0.004 \\
\hline $\begin{array}{l}\text { knowledge in the control and post-intervention } \\
\text { group }\end{array}$ & & & & & & & & & \\
\hline Comparative analytical statistical high-level & & & & & & & & & 0.520 \\
\hline knowledge in the control and post-intervention & & & & & & & & & \\
\hline
\end{tabular}

level of knowledge of hypertension. The comparative statistical analysis between low and high knowledge levels in the three study groups observed (control, pre-, and post-intervention) had a significant difference from the HK-LS questionnaire scores (Table 2). Meanwhile, the comparative statistical analysis of low and high levels of knowledge in the two test groups (control and pre-intervention) showed that there was a statistically significant difference $(p=0.021$ and $p=0.001)$. Comparative statistical analysis on the low-level of knowledge between the control and post-intervention groups had a statistically significant difference $(p=0.004)$ (Table 2).

\section{Performance indicators in hypertension management}

The goal of hypertension health management is to reduce the prevalence of hypertension and control the patient's blood pressure to prevent complications from cardiovascular disease. There needs to be a performance indicator that assesses that every intervention or action taken in the management of hypertension therapy can be seen as giving results or not. Table 3 contains performance indicators of hypertension therapy management expected from this study. There are $5 \mathrm{KPIs}$, including knowledge of hypertension, mean systolic and diastolic blood pressure, the prevalence of hypertensive patients, and prevalence of patients with controlled blood pressure. Based on the $5 \mathrm{KPIs}$ used in this study, it is known that the provision of leaflets provided a good change in terms of increasing knowledge of hypertension, a decrease in the average systolic blood pressure $\geq 140 \mathrm{mmHg}$ and $>90 \mathrm{mmHg}$, and an increase in the percentage of controlled blood pressure (<140/90 $\mathrm{mmHg}$ ) (Table 3 ).

\section{The effect of leaflet on hypertension and blood pressure}

The intervention given in this study was the provision of leaflets containing definitions, limits of blood pressure in hypertension, diet and lifestyle advice, and the importance of adherence to medication consumption according to the regimen recommended by doctors. The effect of giving leaflets on the level of knowledge of hypertension and changes in blood pressure can be seen in Table 4. Leaflets provided a significant difference between before and after the intervention and between the post-intervention and control groups, respectively, with $p<0.000$ and $p<0.000$. The distribution of leaflets did not provide a significant difference in systolic and diastolic blood pressure in the control and post-intervention groups with a value of $p=0.508$ and $p=0.985$ (Table 4 ). 
Table 3: The KPIs

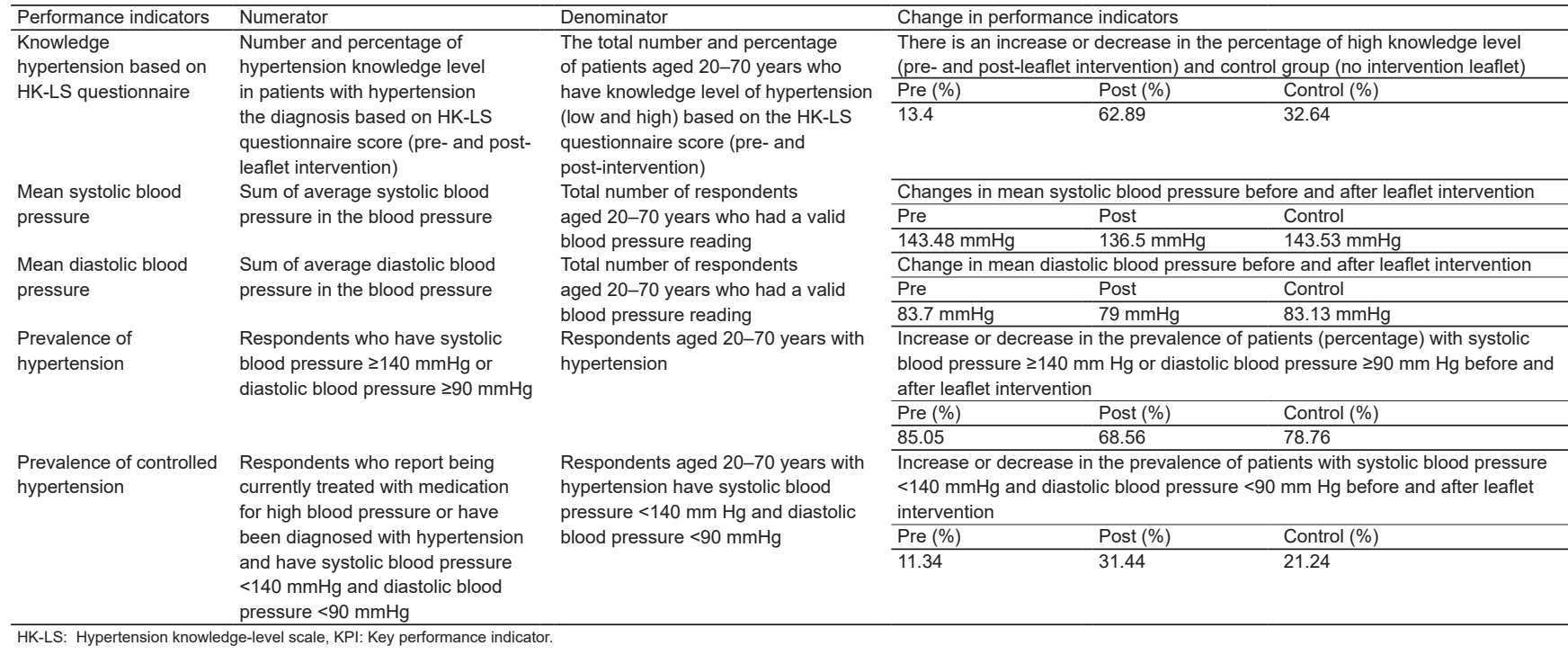

Table 4: The effect of leaflet on hypertension knowledge and blood pressure

\begin{tabular}{lll}
\hline Indicators & Comparative analytical analysis groups & $\mathrm{p}$-value \\
\hline The effect of leaflet on & Pre- and post-intervention group & $<0.001$ \\
hypertension knowledge & Control group and post-intervention group & $<0.001$ \\
The effect of leaflet on systole & Pre- and post-intervention group & $<0.001$ \\
blood pressure & Control group and post-intervention group & 0.508 \\
The effect of leaflet on diastolic & Pre- and post-intervention group & $<0.001$ \\
blood pressure & Control group and post-intervention group & 0.985 \\
\hline
\end{tabular}

\section{Discussion}

Knowledge is the acquisition of information and skills gained from learning and experience [23]. A study of knowledge states that poor knowledge and lack of patient confidence in the treatment of hypertension are among the factors that affect the quality of life [12]. Good respondent's knowledge is influenced by many factors such as experience and information facilities. Hypertension is associated with lifestyle modifications, including several non-pharmacological approaches such as diet adjustments, physical exercise, and blood pressure monitoring [21]. Knowledge of hypertension is very important to prevent hypertension as an important factor in regulating and controlling blood pressure [24].

Good patient knowledge about hypertension will affect patient adherence in taking medication. Hypertension can be controlled if risk factors are controlled. To support this, it is necessary to evaluate the knowledge of hypertension for each individual. So that instruments need to be developed to improve understanding of hypertension both of the things that need to be done and should be avoided (lifestyle) as well as adherence to the consumption of antihypertensive drugs in hypertensive patients. Educational instruments developed included providing leaflets containing information on hypertension. Providing effective health interventions to hypertensive patients can prevent the occurrence of more severe complications from hypertension, including cardiovascular [25].

The measurement of hypertension knowledge in this study uses the HK-LS questionnaire which was previously translated into Indonesian and tested for validation and reliability. Measurement of the level of knowledge in this study uses the HK-LS questionnaire [20], which the researcher has translated into Indonesian version and tested for validation and reliability. Based on the validity test, it was known that all HK-LS statement items were valid. For the reliability test, it was known that the Cronbach's alpha coefficient of hypertension was 0.758 ( $\alpha$-Cronbach $>0.6)$.

Based on the data characteristics of the research subjects known that the total number of research subjects was 387 with details of the control group of 193 respondents and the leaflet intervention group of 194 respondents. The majority of respondents in the control and treatment groups were female (Table 1). A high percentage of hypertensive patients in women, this result is following previous studies by Gillis and Sullivan [25], Woodham et al. [6], and the Indonesian national research data center in 2018. The level of hypertension knowledge in the control group dominated by female respondents has a low level of knowledge $(44.84 \%)$. The age range that most suffer from hypertension in this study is the age between 41 and 60 years (as much as $53.89 \%$ in the control group and $56.7 \%$ in the intervention group), followed by age $>60$ years which is also quite high, namely $41.97 \%$ (control group) and $38.66 \%$ (intervention group) (Table 1). These results are in line with the average age of hypertensive patients at the results of the Indonesian national research center [5]. Based on the results of the analysis, it is known that the percentage of the low level of knowledge is in the age group $>40$ years (before intervention), this is following with the study that the prevalence of a low level of knowledge is found in the group of elderly [19,] [26] (Table 2). 
Increased age affects the increasing prevalence of hypertension [27]. Poor knowledge of hypertension can result in low awareness and adherence in hypertension therapy management so that it can lead to uncontrolled blood pressure [22]. Knowledge and education about hypertension are two important things in controlling blood pressure in hypertensive patients [28]. In other studies, it is known that poor knowledge and education about hypertension can lead to a lack of understanding of hypertension [29].

The majority type of therapy used by respondents in these patients is monotherapy (a type of antihypertensive drug). This is appropriate because the location of the data collection in this study is the primary health center or health facility where the majority of patients do not experience severe disease complications so that antihypertensive drugs are used by the majority of monotherapy drugs. The education level of the majority of the respondents in this study was Senior High School (36\% each in the control and intervention group) (Table 1).

Systolic blood pressure that exceeds normal in the intervention group (pre and post) influences the level of knowledge of hypertension. The comparative statistical analysis between low and high knowledge levels in the three study groups observed (control, pre-, and post-intervention) had a significant difference from the HK-LS questionnaire scores (Table 2). Meanwhile, the comparative statistical analysis of low and high levels of knowledge in the two groups (control and post-intervention) showed that there was a statistically significant difference $(p<0.001)$. Comparative statistical analysis on the low level of knowledge between the control and post-intervention groups had a statistically significant difference $(p=0.004)$ (Table 2). This means that there is a statistically significant difference in patients with a low level of knowledge of hypertension in the control group (who were not given the leaflet intervention) with the post-intervention leaflet group.

The level of knowledge in the majority of the control and pre-intervention group had a low level of adherence (HK-LS score $\leq 17$ ). The percentage increase in knowledge before and after the leaflet can be given for each characteristic of the study subjects can be seen in Table 2. It is known that there was an increase in the high level of knowledge about hypertension in the intervention group with an increase in percentage by $49.49 \%$ from before to after leaflet intervention. Individual characteristics on the level of knowledge of hypertension, such as gender, age, type of therapy, and level of education, do not affect the level of knowledge of hypertension (low and high level). Another study by Lugo-Mata et al. [24] shows that there is no relationship between gender and education level on the level of knowledge. Another study by Grad et al. [30] found that the level of education did not affect the level of knowledge of hypertension, which results were similar to this study. In this study, it is known that high systolic blood pressure $(\geq 140 \mathrm{mmHg}$ ) in patients in the intervention group influences the level of knowledge of hypertension (Table 2). The condition of increased blood pressure can influence people to get more information regarding hypertension.

Performance indicators are intended to facilitate priority intervention to populations and communities where there are significant opportunities for improved therapy and can provide useful information to enable policy changes or implementation of systems designed to reduce the burden of hypertension-related diseases [31]. Several studies suggest that there are performance indicators that can be used to assess hypertension control efforts at organizational level health services [32], [33]. In this study, 5 key indicators of performance were made, including knowledge of hypertension, mean systolic and systolic blood pressure, the prevalence of hypertension, and prevalence of controlled blood pressure. Based on the research data, it is known that from $5 \mathrm{KPIs}$, there is an increase in the percentage of respondents who have a high level of knowledge of hypertension, a high average systolic blood pressure ( $\geq 140 \mathrm{mmHg}$ ), and an average high diastolic pressure $(\geq 90 \mathrm{mmHg}$ ) which has decreased from the group before and after leaflet intervention. The prevalence of hypertension (blood pressure $\geq 140 / 90$ $\mathrm{mmHg}$ ) decreased by about $16.49 \%$ between before and after leaflet administration, the percentage of controlled blood pressure $<140 / 90 \mathrm{mmHg}$ increased by about $20.1 \%$ (Table 3 ). Based on the results of the analysis based on leaflet performance indicators, it can improve knowledge of hypertension and blood pressure control in the intervention group.

Based on statistical analysis, it is known that the administration of leaflets has an influence on the level of hypertension knowledge from two groups of respondents, namely, the control and intervention groups, with a Mann-Whitney test $(p<0.001)$. The Wilcoxon analysis results for pre- and post-intervention data $(p<0.001)$ (Table 4). The results of this statistical analysis indicate that the provision of leaflets showed a significant difference between the pre-test and post-test groups in terms of increasing knowledge of hypertension. This is consistent with previous research that educational interventions such as booklets can increase knowledge [34]. Educational intervention in patients can be a motivation and strategy by health workers in increasing patient adherence in controlling blood pressure [3]. Interventions can be used to increase knowledge of hypertension in hypertensive patients and the general public. Previous research states that educational interventions and approaches to increasing treatment confidence can increase adherence to drug consumption [35]. In the blood pressure control indicators, namely, systolic and diastolic blood pressure, it is known that the leaflet intervention only gave a significant difference between the pre- and post-intervention groups with $p<0.001$, 
but systolic and diastolic blood pressure between the control and post-intervention groups did not provide a statistically significant difference with the value statistical significance $p=0.508$ and $p=0.985$, respectively (Table 4).

The weakness of this research is that there has not been an in-depth analysis of aspects or dimensions that affect the level of knowledge so that it can be known factors that influence the low level of knowledge of hypertension. Based on these results, further research can be done that can increase public knowledge of hypertension about lifestyle, food, even the effect of uncontrolled blood pressure.

\section{Conclusion}

Interventions to improve knowledge of hypertension are expected to have an impact on increasing hypertension knowledge in hypertension patients. Based on the results of this study, it is known that the provision of leaflets can increase the level of hypertension knowledge as measured using the HK-LS questionnaire in pre- and post-leaflet intervention groups.

\section{Authors' Contributions}

Concept - I.E., S.S.F., S.N.P; Design - I.E., S.S.F.; Supervision - I.E.; Resources - I.E., S.S.F.; Materials - I.E., S.N.P.; Data Collection and Processing - I.E., S.N.P.; Analysis and Interpretation - - I.E., S.S.F.; Literature Search - I.E., - I.E., S.N.P; Writing I.E., S.N.P.; Critical Reviews - I.E., S.S.F., S.N.P.

\section{References}

1. Athiyah $U$, Rahem $A$, Setiawan $C D$. The influence of participation of the social security agency (BPJS) health on therapeutic success in hypertension patients at community health centers. Res J Pharm Tech. 2019;12(1):93-8. https://doi. org/10.5958/0974-360x.2019.00018.0

2. Kearney PM, Whelton M, Reynolds K, Muntner P, Whelton PK, He J. Global burden of hypertension: Analysis of worldwide data. Lancet. 2005;365(9455):217-23. https://doi.org/10.1016/ s0140-6736(05)17741-1

PMid:15652604

3. Burnier M, Egan BM. Adherence in hypertension. Circ Res. 2019;124(7):1124-40.

PMid:30920917

4. Kementerian Kesehatan Republik Indonesia. Riset Kesehatan
Dasar. Jakarta: Kementerian Kesehatan Republik Indonesia; 2018.

5. Mills KT, Bundy JD, Kelly TN, Reed JE, Kearney PM, Reynolds K, et al. Global disparities of hypertension prevalence and control: A systematic analysis of population-based studies from 90 countries. Circulation. 2016;134(6):441-50. https://doi. org/10.1161/circulationaha.115.018912

PMid:27502908

6. Woodham N, Taneepanichskul S, Somrongthong R. Medication adherence and associated factors among elderly hypertension patients with uncontrolled blood pressure in rural area, Northeast Thailand. J Health Res. 2018;32(6):449-58. https:// doi.org/10.1108/jhr-11-2018-085

7. World Health Organization. Hypertension; 2018. Available from: https://www.who.int/news-room/fact-sheets/detail/hypertension. [Last accessed on 2020 Jul 05].

8. Ernawati I, Hidayati HB, Sumarno S. The Effects of telmisartan neuroprotection on stroke with hypertension. Malang Neurol $\mathrm{J}$. 2020;6:41-6. https://doi.org/10.21776/ub.mnj.2020.006.01.9

9. Widyaningrum DA, Nilamsari WP, Islamiyah WR, Shinta DW. The patterns of antihypertensive drugs use in acute hemorrhagic stroke patients. Res J Pharm Tech. 2020;13(2):547-54. https:// doi.org/10.5958/0974-360x.2020.00103.1

10. Fandinata SS, Darmawan R. Perbedaan kepatuhan minum obat pada pasien yang baru terdiagnosa dan sudah lama terdiagnosa penyakit diabetes melitus Tipe 2. J Ilmiah Manuntung. 2020;6(1):70-6. https://doi.org/10.32922/jkp.v8i1.118

11. Hill MN, Miller NH, Degeest S, American Society of Hypertension Writing Group. Adherence and persistence with taking medication to control high blood pressure. J Am Soc Hypertens. 2011;5(1):56-63.

12. Saleem F, Hassali MA, Shafie AA, Atif M, UI Haq N, Aljadhey H. Disease related knowledge and quality of life: A descriptive study focusing on hypertensive population in Pakistan. South Med Rev. 2012;5(1):47-52. https://doi.org/10.1016/j.jval.2012.08.221 PMid:23093899

13. Barr PJ, Brady SC, Hughes CM, McElnay JC. Public knowledge and perceptions of connected health. J Eval Clin Pract. 2014;20(3):246-54. https://doi.org/10.1111/jep.12118 PMid:24661432

14. Cohn ES, Cortés DE, Fix G, Mueller N, Solomon JL, Bokhour BG. Habits and routines in the daily management of hypertension. J Health Psychol. 2012;17(6):845-55. PMid:22108291

15. Chotisiri L, Yamarat K, Taneepanichskul S. Exploring knowledge, attitudes, and practices toward older adults with hypertension in primary care. J Multidiscip Healthc. 2016;9:559-64. https://doi. org/10.2147/jmdh.s112368

PMid:27822057

16. Ernawati I, Islamiyah W. Uji validitas dan reliabilitas kuesioner kepatuhan MGLS (morisky, green, levine adherence scale) versi bahasa Indonesia terhadap pasien epilepsi. J IImiah Ibnu Sina. 2019;4(2):305-13. https://doi.org/10.36387/jiis.v4i2.330

17. Ernawati I, Islamiyah WR, Sumarno S. How to improve clinical outcome of epileptic seizure control based on medication adherence: A literature review. Open Access Maced J Med Sci. 2018;6(6):1174-9. https://doi.org/10.3889/oamjms.2018.235 PMid:29983823

18. Ekpenyong CE, Udokang NE, Akpan EE, Samson TK. Double burden, non-communicable diseases and risk factors evaluation in Sub-Saharan Africa: The Nigerian experience. Eur J Sustain Dev. 2012;1(2):249-70. https://doi.org/10.14207/ejsd.2012. v1n2p249

19. Ozoemena EL, Iweama CN, Agbaje OS, Umoke PC, Ene OC, Ofili PC, et al. Effects of a health education intervention on hypertension-related knowledge, prevention and self-care 
practices in Nigerian retirees: A quasi-experimental study. Arch Public Health. 2019;77:23. https://doi.org/10.1186/ s13690-019-0349-x

PMid:31143446

20. Erkoc SB, Isikli B, Metintas S, Kalyoncu C. Hypertension knowledge-level scale (HK-LS): A study on development, validity and reliability. Int J Environ Res Public Health. 2012;9:1018-29. https://doi.org/10.3390/ijerph9031018

PMid:22690180

21. Buang NF, Rahman NA, Haque M. Knowledge, attitude and practice regarding hypertension among residents in a housing area in Selangor, Malaysia. Med Pharm Rep. 2019;92(2):14552. https://doi.org/10.15386/mpr-1227 PMid:31086842

22. Jankowska-Polańska B, Uchmanowicz I, Dudek K, Mazur G. Relationship between patients knowledge and medication adherence among patients with hypertension. Patient Prefer Adherence. 2016;10:2437-47. https://doi.org/10.2147/ppa. s117269

PMid:27994443

23. Eshah NF, Al-Daken LI. Assessing public's knowledge about hypertension in a community-dwelling sample. J Cardiovasc Nurs. 2016;31(2):158-65. https://doi.org/10.1097/ jcn. 0000000000000227

\section{PMid:25658184}

24. Lugo-Mata AR, Urich-Landeta AS, Andrades-Pérez AL, LeónDugarte MJ, Marcano-Acevedo LA, Guillen MH. Factors associated with the level of knowledge about hypertension in primary care patients. Med Univ. 2017;19(77):184-8.

25. Gillis EE, Sullivan JC. Sex differences in hypertension: Recent advances. Hypertension. 2016;68(6):1322-7. https://doi. org/10.1161/hypertensionaha.116.06602

PMid:27777357

26. Kaczorowski J, Chambers LW, Karwalajtys T, Dolovich L, Farrell $\mathrm{B}$, McDonough B, et al. Cardiovascular health awareness program (CHAP): A community cluster-randomised trial among elderly Canadians. Prev Med. 2008;46(6):537-44. https://doi. org/10.1016/j.ypmed.2008.02.005

PMid:18372036

27. KwonMJ,AhnSY.Factorsaffecting blood pressurecontrolinelderly Koreans with hypertension. Res J Pharm Tech. 2018;11(4):1398403. https://doi.org/10.5958/0974-360x.2018.00261.5
28. Han HR, Chan K, Song $H$, Nguyen T, Lee JE, Kim MT. Development and evaluation of a hypertension knowledge test for Korean hypertensive patients. J Clin Hypertens (Greenwich). 2011;13(10):750-7. https://doi. org/10.1111/j.1751-7176.2011.00497.x

PMid:21974763

29. Lee JE, Han HR, Song H, Kim J, Kim KM, Ryu JP, et al. Correlates of self-care behaviors for managing hypertension among Korean Americans: A questionnaire survey. Int J Nurs Stud. 2010;47(4):411-7. https://doi.org/10.1016/j.ijnurstu.2009.09.011 PMid:19863959

30. Grad I, Mastalerz-Migas A, Kiliś-Pstrusińska K. Factors associated with knowledge of hypertension among adolescents: Implications for preventive education programs in primary care. BMC Public Health. 2015;15:463. https://doi.org/10.1186/ s12889-015-1773-7

PMid:25935154

31. Campbell N, Ordunez P, Jafe M, Orias M, DiPete D, Patel P, et al. Implementing standardized performance indicators to improve hypertension control at both the population and healthcare organization levels. J Clin Hypertens (Greenwich). 2017;19(5):456-61. https://doi.org/10.1111/jch.12980 PMid:28191704

32. Suija K, Kivisto K, Sarria-Santamera A, Kokko S, Liseckiene I, Bredehorst $\mathrm{M}$, et al. Challenges of audit of care on clinical quality indicators for hypertension and Type 2 diabetes across four European countries. Fam Pract. 2015;32(1):69-74. https:// doi.org/10.1093/fampra/cmu078 PMid:25411423

33. Rogers T, Chappelle EF, Wall HK, Barron-Simpson R. Using DHDSP Outcome Indicators for Policy and Systems Change for Program Planning and Evaluation. Atlanta, GA: Centers for Disease Control and Prevention; 2011.

34. Dawes MG, Kaczorowski J, Swanson G, Hickey J, Karwalajtys T. The effect of a patient education booklet and BP tracker on knowledge about hypertension. A randomized controlled trial. Fam Pract. 2010;27(5):472-8. https://doi.org/10.1093/fampra/ cmq048

PMid:20631056

35. Khalil W, Tartour M. Effect of Health education intervention on improving compliance to treatment among hypertensive patients. J Hypertens. 2017;35:e16. https://doi.org/10.1097/01. hjh.0000523022.45839.02 